\title{
IMPROVING THE QUALITY OF HUMAN RESOURCES IN MADRASAH
}

\author{
Yudik Al Farisi* \\ Universitas Nurul Jadid, Probolinggo, East Java, Indonesia
}

DOI: https://doi.org/10.52627/ijeam.v3i2.156

Article History:

Received: July 2021

Accepted: August 2021

Published: August 2021

\section{Keywords:}

Quality, Human Resources,

Madrasah

*Correspondence Address: yudialfarisih10@gmail.com

\section{Abstract :}

This study aims to understand how to create superior quality human resources in Madrasah Aliyah Nurul Jadid, Paiton, Probolinggo, East Java. This research is a case study qualitative research, in which researchers seek to understand the phenomena in improving the quality of superior human resources in madrasas. The results of this study indicate that the efforts made by madrasas in creating excellent quality human resources are carried out through, first, in-service training, namely education and training efforts to improve the competence and skills of teachers and employees. Second, the creation of an organizational culture that can encourage success. Third, making clear standard operating procedures to ensure that all decisions made are carried out correctly. Fourth, supervision and assessment as a medium that knows and measures the performance of existing resources.

\begin{abstract}
Abstrak :
Penelitian ini bertujuan untuk memhami tentang bagaimana menciptakan kualitas sumber daya manusia yang unggul di Madrasah Aliyah Nurul Jadid, Paiton, Probolinggo, Jawa Timur. Penelitian ini merupakan penelitian kualitatif jenis studi kasus, di mana peneliti berusaha untuk memahami tentang fenomena dalam peningkatan kualitas sumber daya manusia yang unggul di madrasah. Hasil penelitian ini menunjukkan bahwa dalam upaya yang dilakukan oleh madrasah dalam menciptakan kualitas sumber daya manusia yang unggu dilakukan melalui; pertama, in-service training yaitu usaha pendidikan dan pelatihan dalam meningkatkan kompetensi dan keterampilan guru dan karyasan. Kedua, penciptaan budaya organisasi yang dapat mendorong untuk mencapai keberhasilan. Ketiga, pembuatan standard operasional procedure yang jelas guna memastikan segala keputusan yang ditetapkan berjalan semestinya. Keempat, Pengawasan dan penilaian sebagai media yang mengetahui dan mengukur kinerja sumber daya yang ada.
\end{abstract}




\section{INTRODUCTION}

Improving the quality of human resources (HR) is an absolute prerequisite for achieving development goals. One of the vehicles to enhance the quality of human resources is through superior and competitive education (Baharun, 2016; Bukit et al., 2017; Badrudin et al., 2021). Education has a vital role in the survival of human life. Education can make people intelligent, creative, responsible, and productive (Susilowati \& Farida, 2019; Purnomo et al., 2021).

Education plays a vital role in the survival of human life. Starting from success in education, a nation can become advanced (Masram \& Mu'ah, 2015; Mahmud \& Sanusi, 2021; Atika et al., 2021; Kristanto et al., 2021). Through education, quality human resources are printed to become a driving force for the progress and prosperity of the nation (Kalangi, 2015; Elbadiansyah, 2017; Mahmud \& Sanusi, 2021). Development in the field of education today is constantly increasing. This is in line with the development of society that demands quality improvement and quality in the field of education (Fauzi, 2020). However, efforts are still needed to determine the right way so that skills and skills can be mastered by students who will indirectly improve the quality of education in a better direction (Suwatno', 2002; Silviani et al., 2021).

At this time, the Indonesian people are entering the era of globalization and modernization, which is full of challenges that require them to become more high-quality human beings with broad insight and all the skills they have. Along with advances in science and technology, every organization must be able to implement, utilize, and manage it (Krismiyati, 2017).

The quality of existing human resources determines the progress of a nation. Developing an era that is so advanced today is meaningless if qualityhuman resources do not support it (Umiarso, 2016; Dakir et al., 2020). The point is that human resources are an essential element in advancing a nation (Mantiri, 2019; Yuliyati, 2020; Noor \& Juhji, 2020). It can be said that the quality of human resources is an individual who makes a valuable contribution to the achievement of organizational goals through the competencies and skills possessed by the person in the organization (Hasibuan \& Prastowo, 2019).

Indonesia is currently facing problems related to the quality of human resources $(\mathrm{HR})$, resulting in low development efficiency. According to The Human Capital Index 2020 (HCI) issued by the World Bank, Indonesia's HR development index from 2008 was $0.53 \%$, experiencing an increase in 2020 by 0.54\%. According to the Central Statistics Agency, Probolinggo Regency in 2019 was the 4th poorest district in East Java. The low quality of human resources influences this. From the previous data, Madrasah Aliyah Nurul Jadid prioritizes improving the quality of superior human resources.

Madrasah Aliah Nurul Jadid Paiton is a formal institution located near the coast of the Nurul Jadid Islamic Boarding School. Human resources are still low, so that it is necessary to develop and improve the quality of human resources, especially for academic staff. With the Madrasah Aliyah Nurul Jadid institution, it is expected to be able to create superior quality human resources and be able to compete. 
The education sector can contribute to improving the quality of human resources. Education equips individuals with the subject matter and skills and instills values and ethics (Wahid et al., 2020). That way, economic growth is not only supported by significant capital but also quality human resources. So that it will make economic growth better (Hamer et al., 2020).

Many types of research on HR have been carried out, among others, according to Krismiyati (2017), with the title Human Resource Development in Improving the Quality of Education at the Inpres Angkasa Biak Elementary School. The study results showed that human resource development efforts were going well, but the training was not maximally carried out.

According to Mantiri (2019), the role of education in creating quality human resources in North Sulawesi Province. This study indicates that in the world of education, teachers as human resources in educational institutions are tasked with creating new quality human resources. The difference with the research to be carried out lies in the educational institution used as the research location, namely madrasah aliyah, and has similarities in researching human resources.

Based on the research above, this research is unique and novel in researching human resources. Researchers, in this case, are trying to study and analyze how to create superior quality human resources (HR) in Madrasah Aliyah Nurul Jadid, Paiton, Probolinggo, East Java.

\section{RESEARCH METHODS}

This research is qualitative research with the type of case study. The location of this research is Madrasah Aliyah Nurul Jadid which is located in the Pondok Pesantren Nurul Jadid Paiton Probolinggo. This study aims to research and find out about how to create superior quality human resources.

Sources of information in this study were principals and teachers because they know about the information desired by researchers. To get a general understanding of the superior quality of human resources in madrasas, the researchers used observation techniques, interviews with principals and teachers, and documentation to complement the data that the researchers studied.

Data analysis begins with presenting the data as a whole, then simplifies the data, namely grouping and selecting the collected data according to a predetermined theme, and finally ending the data analysis by drawing research conclusions as research results.

\section{RESEARCH RESULTS AND DISCUSSION}

In creating superior quality human resources in madrasas, the things that madrasas do are as follows;

\section{In-Service Training}

In-Service Training can be interpreted as an educational and experience effort to improve the expertise devoted to teachers to align and enhance their knowledge in their respective fields according to their duties to increase efficiency and productivity in carrying out these tasks. 
According to IF1, as the Head of Madrasah, he said that educators continuously improve professionalism and quality to become superior educators. This is necessary by following the development of human, which is increasingly advanced with technological sophistication. Thus, the ability of a teacher can continually improve and develop professionalism and increase knowledge. Some efforts need to be made, including the following:

First, teachers need to improve and update knowledge at home, in the library, and on the internet. Human resource development is enhanced according to their respective fields. According to IF2, as a teacher, a teacher must continually improve the quality and professionalism of an educator with various efforts and efforts by his expertise.

Thus teachers in improving and developing quality as superior human resources with various efforts and efforts. Quality improvement is carried out mainly in the world of education, which continuously updates knowledge. According to IF3, as a teacher, educators are human resources who are prepared as the nation's successors in the world of education. So the development and improvement of the quality of students must continue to be updated according to their knowledge. Education is a critical and influential stage for the future, so that it is necessary to develop and develop superior and quality human resources.

Second, teachers are expected to take advantage of forums and organizations to share knowledge, discussions, and seminars. According to IF2, it is said that updating knowledge can be done anywhere, one of which is with teacher organizations, participating in various seminars and training so that they have a place to channel their knowledge.

The utilization of communities and associations as a forum for learning together can increase superior human resources. The activities carried out can be used as an effective effort to improve and develop education.

Third, teachers and students can improve formal education in stages. Fourth, attending meetings of educational organizations and communities. Fifth, taking part in scientific competitions, and Sixth, conducting research and scientific writings.

According to IF1, a teacher always develops knowledge to become helpful for his students. An example is in academics, which continuously improve its quality and continue the academic level. This progress shows that a teacher must constantly update knowledge and improve quality as a superior human resource. Improvement is accompanied by continuous and continuous progress of the times.

\section{Creation of Work Culture}

Work culture encourages the achievement of organizational success or goals. The way of working is based on a value system that every teacher holds. The method of working is realized like that because it has become a habit or tradition.

According to IF1, every educational institution has its own work culture. Good work culture must continue to be improved, and vice versa, a bad work 
culture must be abandoned.

Changes in the environment will have an impact on how we achieve our objectives. Outside demands and cultural norms have a considerable effect on the ability to transform work culture. In such conditions, teachers need to make changes to the work culture that is not good. Teachers as human resources (HR) in madrasa institutions must be proactive in solving problems in anticipating patterns of change in human resources. To obtain optimal results, one must direct changes in human behavior to create superior and quality human resources.

Cultural change is defined as providing the broadest possible opportunity for teachers to achieve self-actualization. It can be transmitted through learning methods (learning organization), namely through examples, socialization, and internalization. Internalization is the process of developing a value or culture to become a teacher's self and is more qualitative.

According to IF2, teachers must quickly adapt to a new work culture in learning methods but must be good at choosing good and bad cultures.

A new culture can be created with various strategies, namely, dissolving current behavior patterns and making the need for change so apparent that individuals and groups can easily understand it. Second, change in this regard requires developing related values, attitudes, and behaviors during the identification and internalization process. Third, the provision of norms, which is to strengthen new behavior through supporting or reinforcing mechanisms so that it becomes the new norm

\section{Clear Standard Operating Procedures}

SOP (Standard Operating Procedures) is a guideline or standard steps that intend to ensure that all decisions or actions taken have been carried out correctly. Standard Operating Procedures (SOPs) can provide various benefits, one of which is to develop human resources.

According to IF1, it says that in madrasas, clear and binding SOP rules have been established. All madrasa academics must obey these regulations.

With the SOP, it is possible to consistently maintain human resources' performance and know the duties, responsibilities, and authorities they have. In addition, SOPs also become a solid legal basis if bad things occur that can be detrimental. In creating superior human resources, there are several aspects in standard operating procedures, including:

First, Provide Operational Guidelines. So far, the regulations or operational guidelines have not been understood by all teachers. Therefore, to be aware of the role of the SOP guidelines, new rules are needed that are standard so that all teachers are obliged to obey them.

Second, to become a reference for accountability. An SOP in teacher development can provide benefits and be used as a reference for the person in charge of learning activities. Until now, the SOP has become a tool to oversee various kinds of work so that it can be carried out correctly and according to its original purpose. 
They are third, Streamlining Work Activities. As a human resource development process, it turns out that standard operating procedures in a company can provide benefits, namely providing smooth work in every teacher activity. Every task will be carried out with a complete sense of responsibility so that all activities can run according to purpose and smoothly.

It was fourth, Determining Employee Performance Standards. At the work level or in one field of work, of course, requires work qualifications that match the teacher's expertise. From there, the standard of a teacher is needed to improve superior quality.

Fifth, Choose Training Standards. Not only from teacher standards, the SOP for training and human resource development also concerns training standards. According to IF3, the SOP that has been set together must be adhered to so that quality as a teacher can be achieved. The standard of work of a teacher is always required to be improved.

Improving and developing the quality of human resources in a teacher can be done consistently with various binding regulations. So that teachers can think critically to improve the quality of a teacher.

\section{Work Supervision and Appraisal}

An important aspect that needs to be considered in monitoring and evaluating work is the condition of the HR performance. To determine the performance of existing human resources, it is necessary to monitor and assess their performance. Performance appraisal includes the dimensions of teacher performance and accountability. Supervision and performance appraisal relates to how far HR is carrying out its duties and responsibilities.

According to IF1, supervision and assessment of teachers are essential to determine how far the quality of teacher performance is in developing the mandate given to them.

Thus, efforts to improve performance and teacher development programs must start from understanding the current level of performance regarding the results achieved and their competencies. This step is the basis for identifying development needs and improving employee performance.

HR performance measurement is helpful for career development, and continuous development includes strengths that must be improved and weaknesses that must be overcome. According to IF3, teacher performance is assessed consistently; at the end of each semester, madrasas evaluate all teachers to find out and anticipate obstacles in working.

Performance appraisal begins with collecting data on the performance of teachers throughout the performance evaluation period. Data collection was done through observations about what the teachers were doing. The principal of the madrasah observes and monitors teacher performance and conducts accurate documentation, namely recording in a workbook or in a particular instrument to record observations.

Theoretically, it can be seen that human resources are people in the organization who contribute ideas and do various types of work in achieving organizational goals (Suwatno', 2002). The contribution in question is the 
thoughts and work they do in multiple activities within the company. In terms of human resources, what is covered is not limited to experts, educational staff, or experienced personnel, but all workers used to realize its goals (Setyosari, 2014).

The explanation of humans as resources shows that humans are unique and complex creatures. In working in a company environment, they must be treated with a good quality of work-life to enable them to work effectively, efficiently, productively, and with quality (Hasibuan \& Prastowo, 2019). Among them are providing opportunities to develop their careers, being treated fairly in resolving the conflicts they face, being supervised honestly and objectively, getting decent wages, and others (Sudaryanti et al., 2020).

Education with training is an inseparable series in the human resource development system, in which there is a process of planning, placing, and developing human resources (Mantiri, 2019). In the development process, efforts are made so that human resources can be maximally empowered so that the goal of meeting the needs of human life can be fulfilled. It isn't easy to draw firm boundaries between education and training because both general education and training are processes of learning activities that transfer knowledge and skills from the source to the recipient. However, the difference between the two will be seen from the goals to be achieved through these activities (Tanu, 2019).

Human resource development is also an effective way to overcome some of the challenges faced. The current increase in human resources can be seen as a growth in ability far beyond what is required in a job (Kalangi, 2015). Quality and reliable human resources will determine the progress of an educational institution. To obtain quality human resources, it is necessary to make improvements with various training by the science of human resource management (Hasima, 2020).

Education helps improve theoretical, conceptual, and human attitudes or moral skills. At the same time, training aims to improve technical skills in implementing specific jobs and attitudes so that they are more skilled and able to carry out responsibilities according to standards. Thus it can be interpreted that education and training are determinants of the quality of human resources (Susilowati \& Farida, 2019).

\section{CONCLUSION}

Creating quality human resources (HR) is part of the process and goals in national development. Improving the quality of superior human resources, especially in education, can make a strong nation and a prosperous country. A quality education system is a guide in creating quality human resources.

In Madrasah Aliyah, Nurul Jadid plays an active and full role in structuring a quality education system and strengthening the Islamic religion to improve the personality of human resources. Improvement, guidance, and development of the superior quality of human resources at Madrasah Aliyah Nurul Jadi have been carried out with various efforts and efforts to produce excellent human resources. Thus the human resources at MA Nurul Jadid have been prepared and possible so that they can be competitive. 
Limitations Research conducted by researchers is aware that there are still shortcomings, but researchers are trying their best in conducting this research. So that further research is needed on creating superior quality Human Resources (HR).

\section{REFERENCES}

Atika, Arifin, Z., \& Jannana, N. S. (2021). Integrated School ManagementCharacter Education Affirmation: A Case Study in Muhammadiyah Wirobrajan 3 Elementary. Al-Tanzim: Jurnal Manajemen Pendidikan Islam, $5(2), 15-26$.

Badrudin, Gustini, N., \& Amirullah, C. I. (2021). Correlation of Financing Management Towards The Quality of Education in Madrasah Diniyah Takmiliyah Awaliyah in Bandung District. Al-Tanzim: Jurnal Manajemen Pendidikan Islam, 5(2), 96-104.

Baharun, H. (2016). Manajemen Kinerja Dalam Meningkatkan Competitive Advantage Pada Lembaga Pendidikan Islam. At-Tajdid: Jurnal Ilmu Tarbiyah, 5(2), 243-262.

Bukit, B., Malusa, T., \& Rahmat, A. (2017). Pengembangan Sumber Daya Manusia. Teori, Dimensi Pengukuran,

Dakir, Fauzi, A., \& Anwar, K. (2020). Pesantren Quality Management; Government Intervention In The Policy of The Pesantren Law In Indonesia. International Journal of Innovation, Creativity and Change, 3(14), $1603-1620$.

Elbadiansyah. (2017). Mutu Pendidikan pada Perguruan Tinggi Keagamaan: Dari Manajemen Kelembagaan Hingga Konstruksi Kurikulum Interrelasi. Muaddib:Studi Kependidikan Dan Keislaman, 7(1), 47-66. https:/ / doi.org/10.24269/muaddib.v7n1.2017.47-66

Fauzi, A. (2020). Manajemen Mutu Pendidikan Islam Terpadu; Strategi Pengelolaan Mutu Madrasah dan Sekolah di Era Revolusi Industri 4.0. Yogyakarta: Pustaka Pelajar.

Hamer, W., Pujakesuma, T. A. R., Lisdiana, A., Purwasih, A., Karsiwan, K., \& Wardani, W. (2020). Menyiapkan Sumber Daya Manusia Unggul Melalui Penanaman Nilai-Nilai Religius Pada Kegiatan Keagamaan Di Desa Pulau Pehawang Kecamatan Marga Punduh. DEDIKASI: Jurnal Pengabdian Masyarakat, 2(1), 42-54.

Harjanti, S. (2004). Menciptakan Keunggulan Bersaing Yang Berkelanjutan Melalui Manajememen Sumber Daya Manusia. Jurnal Ekonomi Dan Kewirausahaan, 4(1), 411-455.

Hasibuan, A. T., \& Prastowo, A. (2019). Konsep Pendidikan Abad 21: Kepemimpinan Dan Pengembangan Sumber Daya Manusia Sd/Mi. MAGISTRA: Media Pengembangan Ilmu Pendidikan Dasar Dan Keislaman, 10(1), 26-50. https:/ / doi.org/10.31942/mgs.v10i1.2714 
Hasima, R. (2020). Perlindungan Hukum terhadap Guru dalam Penyelenggaraan Pendidikan di Kota Kendari. Jurnal Ilmu Hukum Fakultas Hukum Universitas Riau, 9(2), 190-209.

Kalangi, R. (2015). Pengembangan Sumber Daya Manusia dan Kinerja. Jurnal LPPM Bidang EkoSosBudKum, 2(1), 1-18.

Krismiyati, K. (2017). Pengembangan Sumber Daya Manusia dalam Meningkatkan Kualitas Pendidikan di SD Negeri Inpres Angkasa Biak. Jurnal Office, 3(1), 43-50. https:// doi.org/10.26858/jo.v3i1.3459

Kristanto, J., Soleh, A. K., Al-Idrus, S., \& Raya, M. K. (2021). Promotion Mix Nahdlatul Ulama University of Surabaya to Increase New Student's Interest. Al-Tanzim: Jurnal Manajemen Pendidikan Islam, 5(2), 1-14.

Mahmud, H., \& Sanusi, S. (2021). Training , Managerial Skills , And Principal Performance At Senior High Shool In North Luwu Regency. Al-Tanzim: Jurnal Manajemen Pendidikan Islam, 5(2), 27-39.

Mantiri, J. (2019). Peran Pendidikan Dalam Menciptakan Sumber Daya Manusia Berkualitas Di Provinsi Sulawesi Utara. Jurnal Civic Education: Media Kajian Pancasila Dan Kewarganegaraan, 3(1), 20. https://doi.org/10.36412/ce.v3i1.904

Masram, \& Mu'ah. (2015). Manajemen Sumber Daya Manusia dan Implementasi dalam Organisasi.

Noor, W., \& Juhji, J. (2020). Integrasi Budaya Prestasi pada Fungsi Perencanaan Pembinaan Mutu Dosen. Al-Tanzim: Jurnal Manajemen Pendidikan Islam, 4(1), 1-12. https:/ / doi.org/10.33650/al-tanzim.v4i1.919

Purnomo, H., Chaer, M. T., \& Mansir, F. (2021). Humanistic Public Service Education in Government Gamping Sub-District Yogyakarta. Al-Tanzim: Jurnal Manajemen Pendidikan Islam, 5(2), 52-61.

Setyosari, P. (2014). Menciptakan Pembelajaran Yang Efektif dan Berkualitas. Jurnal Inovasi Dan Teknologi Pembelajaran, 1(1), 20-30.

Silviani, S., Maarif, M. A., \& Wibowo, A. (2021). Knowledge Sharing Management: Strategy for Improving the Quality of Human Resources. Al-Tanzim: Jurnal Manajemen Pendidikan Islam, 5(1), 129-139. https:/ / doi.org/10.33650/al-tanzim.v5i1.1831

Sudaryanti, Pamungkas, J., \& Syamsudin, A. (2020). Evaluasi pembelajaran tata nilai budaya Yogyakarta di taman kanak-kanak se-kabupaten bantul Yogyakarta. Jurnal Pendidikan Anak, 9(2), 79-85.

Susilowati, S., \& Farida, I. (2019). Strategi Pengembangan Sumber Daya Manusia Di Pt. Gaya Sukses Mandiri Kaseindo ( Safeway) Surabaya. Develop, 3(2), 10-25. https:/ / doi.org/10.25139/ dev.v3i2.1772

Suwatno'. (2002). Strategi Pengembai \Gan Sumber Daya Manusia Indonesia. Manajerial, 1(1), 35-42.

Tampubolon, H. (2014). Strategi manajemen sumber daya manusia dan perannya dalam pengembangan keunggulan bersaing.

Tanu, I. K. (2019). Pentingnya Pendidikan Anak Usia Dini Agar Dapat Tumbuh Dan Berkembang Sebagai Generasi Bangsa Harapan Di Masa Depan. Adi Widya: Jurnal Pendidikan Dasar, 2(2), 19-29. https:/ / doi.org/10.25078/aw.v2i2.960 
Umiarso. (2016). Manajemen Mutu Pendidikan. Jakarta: Kencana.

Wahid, A. H., Najiburrahman, Rahman, K., Faiz, Qodriyah, K., Hambali, Muali, C. (2020). Effectiveness of Android-Based Mathematics Learning Media Application on Student Learning Achievement. Journal of Physics: Conference Series, $1-7 . \quad$ https://doi.org/10.1088/1742$6596 / 1594 / 1 / 012047$

Yuliyati, E. (2020). Pengembangan Sumber Daya Manusia Berbasis Total Quality Management di SMK Muhammadiyah Prambanan. Al-Tanzim: Jurnal Manajemen Pendidikan Islam, 4(1), 24-35. https://doi.org/10.33650/al-tanzim.v4i1.967 